\title{
The effect of graded levels of dietary threonine on nitrogen retention and structure of the small intestine in young pigs
}

\author{
E. Święch ${ }^{1}$, M. Boryczka, M. Taciak and L. Buraczewska \\ The Kielanowski Institute of Animal Physiology and Nutrition, Polish Academy of Sciences \\ 05-110 Jabtonna, Poland
}

(Received 3 March 2011; revised version 19 July 2011; accepted 9 August 2011)

\begin{abstract}
The effects of four levels of dietary threonine (Thr) on growth performance, $\mathrm{N}$ retention and structure of the small intestine were studied in pigs from 13 to $22 \mathrm{~kg}$ of body weight (BW). Four diets were formulated to contain 6.46, 7.43, 8.37 and $9.32 \mathrm{~g}$ Thr. Each diet was fed to six pigs for 19 days and $\mathrm{N}$ balance was determined at $15 \mathrm{~kg} \mathrm{BW}$. Tissue samples of the small intestine were taken for histological and histochemical measurements. In pigs fed Thr-deficient diet, $\mathrm{N}$ retention (g per day) was lower than on diets containing 7.43 and $9.32 \mathrm{~g}$ Thr per kg. Tunica mucosa thickness and number of goblet cells (in villi and/or in crypts) containing neutral mucins were smaller on Thrdeficient diet than on other diets. It can be assumed that the level of dietary Thr amounting about $7.4 \mathrm{~g}$ per kg covers the requirement of piglets from 10 to $25 \mathrm{~kg}$ for rapid growth and maximal $\mathrm{N}$ retention as well as for supporting gut barrier function.
\end{abstract}

KEY WORDS: pigs, threonine, growth performance, nitrogen retention, intestinal morphology, goblet cells

\section{INTRODUCTION}

Threonine (Thr) is often the second or third limiting amino acid (AA) in cereal-based diets for pigs. Variations exist among the reported requirements of Thr for young pigs (13-22 kg); they range from 0.63 to $0.74 \%$ of a diet (Saldana et al., 1994; NRC, 1998; GfE, 2006). These variations may result from pig genotype,

\footnotetext{
${ }^{1}$ Corresponding author: e-mail: e.swiech@ifzz.pan.pl
} 
feeding level, diet composition and experimental conditions. In comparison with the other essential AA, Thr requirement for maintenance is high (Fuller et al., 1989) and this may be explained by special functions of Thr in the intestine. It was found that the intestine utilize about $60 \%$ of dietary Thr (Bertolo et al., 1998; Stoll et al., 1998). This AA is incorporated in the intestine proteins which are mostly secreted into the lumen (Le Floc'h and Séve, 2005; Schaart et al., 2005). Deficiency or excess of Thr reduces the synthesis of intestinal mucosal protein and mucins as well as muscle protein in weaned pigs (Wang et al., 2007). In piglets fed on Thr-deficient diet symptoms of diarrhoea and decreased mucosa weight were recorded (Wang et al., 2007).

The intestinal epithelium is protected against bacterial, chemical and mechanical injures by mucous layer, which is composed mainly of mucins secreted by goblet cells (GC). Mucins are classified into acidic and neutral types. Their proportions vary along the gut. An optimal protection of epithelium depends on both quantitative (thickness) and qualitative properties of mucins. Acidic mucins increase the resistance of mucus against bacterial enzymes (Deplancke and Gaskins, 2001). The increase in GC number in the small intestinal villi may potentially increase the mucin secretion capacity of the mucosa and consequently improve gut health. All mucins are rich in serine, proline and particularly in Thr. Mucin protein is very resistant to digestion in the small intestine and ileal endogenous losses of Thr are high.

In pigs, threonine dehydrogenase (TDG) is one of three enzymes involved in Thr catabolism. Activity of this enzyme was found in the liver and pancreas, but not in the intestine (Le Floc'h et al., 1997; Le Floc'h and Séve, 2005).

The aim of the study was to investigate the effect of increasing dietary Thr level on performance, $\mathrm{N}$ retention, morphology and goblet cell types in the small intestine, and TDG activity in the liver and pancreas of young pigs with a high lean gain potential.

\section{MATERIAL AND METHODS}

\section{Animals and feeding}

The experiment was conducted on twenty four male pigs (synthetic line 990). They were housed individually in metabolism cages with a slatted floor in an environmentally controlled room $\left(22-23^{\circ} \mathrm{C}\right)$ with ad libitum access to water. The experiment was approved by the Local Animal Care Committee.

Pigs were allocated to four groups (six pigs each) taking body weight (BW), age and litters into account. For seven days the pigs were allowed to adapt to the 
cages and were fed a starter diet with daily incremental additions of the test diets. Equal amounts of diets were given three times daily at 08.00, 14.00, and 20.00, after mixing with water (1:1). Pigs (initially about $12.8 \mathrm{~kg} \mathrm{BW}$ ) were fed experimental diets for 19 days. Four experimental diets without antibiotics were formulated: one unsupplemented, Thr-deficient and three diets supplemented with crystalline Thr. Diets contained 6.46, 7.43, 8.37 and $9.32 \mathrm{~g}$ Thr per $\mathrm{kg}$. All diets contained 14.4 MJ $\mathrm{ME}$ and $13.46 \mathrm{~g}$ lysine per $\mathrm{kg}$. Composition of Thr-deficient diet is given in Table 1. The diets were supplemented with crystalline lysine, methionine, tryptophan and valine to cover the AA requirement (except of Thr) of pigs.

Table 1. Composition of threonine-deficient diet

\begin{tabular}{|c|c|}
\hline Item & Threonine-deficient diet \\
\hline \multicolumn{2}{|l|}{ Ingredients, $\mathrm{g} / \mathrm{kg}$} \\
\hline wheat & 550.00 \\
\hline maize & 150.00 \\
\hline soyabean meal & 110.00 \\
\hline full fat soyabeans & 60.00 \\
\hline casein & 20.00 \\
\hline wheat gluten & 56.00 \\
\hline soya oil & 15.00 \\
\hline dicalcium phosphate & 16.00 \\
\hline limestone & 6.00 \\
\hline salt & 3.00 \\
\hline premix $^{1}$ & 5.00 \\
\hline L-lysine $\mathrm{HCl}(78 \%)$ & 6.65 \\
\hline DL-methionine (98\%) & 1.22 \\
\hline L-tryptophan (98\%) & 0.23 \\
\hline L-valine $(98 \%)$ & 0.20 \\
\hline maize starch & 0.70 \\
\hline \multicolumn{2}{|c|}{ Contents of crude protein and total amino acids, $\mathrm{g} / \mathrm{kg}$} \\
\hline crude protein & 213.7 \\
\hline lysine & 13.46 \\
\hline threonine & 6.46 \\
\hline methionine & 4.71 \\
\hline cysteine & 3.80 \\
\hline tryptophan & 2.57 \\
\hline isoleucine & 8.11 \\
\hline arginine & 8.97 \\
\hline histidine & 4.91 \\
\hline
\end{tabular}

\section{Experimental procedure}

At a mean BW of approximately $15 \mathrm{~kg}, \mathrm{~N}$ balance was performed during 14-d period. The daily dietary allowance was provided at a rate of about $5 \%$ of 
$\mathrm{BW}$, and was kept constant during the last nine days of $\mathrm{N}$ balance period. Daily $\mathrm{N}$ intake was the same in all groups $(25.7 \mathrm{~g})$. Faeces and urine were collected during six days according to Buraczewska et al. (2006). Average daily gain (ADG) and feed:gain ratio $(\mathrm{F} / \mathrm{G})$ were measured. Feeding experimental diets was continued till slaughter.

After slaughter at about $22.0 \mathrm{~kg}$ of BW, the entire gastrointestinal tract was immediately removed and the small intestine dissected into the duodenum, jejunum and ileum. After rinsing with cool $0.9 \% \mathrm{NaCl}$ solution, the intestinal segments were weighted and tissue samples were taken from their middle parts for histological and histochemical measurements. Liver and pancreas were weighed and samples were stored at $-80^{\circ} \mathrm{C}$ until determination of TDG activity.

\section{Chemical and histological analyses}

Dry matter in ingredients and diets and nitrogen $(\mathrm{N})$ in ingredients, diets, digesta, faeces and urine were analysed using standard methods (AOAC, 1990). Amino acid analyses of ingredients and Thr-deficient diet were performed with the Beckman high pressure AA analyzer System Gold (Beckman Instruments, Inc. Fullerton, CA, USA) using modified procedures according to Buraczewska and Buraczewski (1984). Tissue samples for histological and histochemical analyses were placed in Bouin's solution, dehydrated and infiltrated with paraffin wax. Two slides were prepared from each sample, and each slide contained minimum of three sections cut at $5 \mu \mathrm{m}$. Sections were stained with haematoxylin and eosin. The parameters determined were as follows: villous height, crypt depth, villous length to crypt depth ratio, thickness of tunica mucosa and myenteron, and villous surface area. The measurements of villous length and crypt depth were made on 30 well-oriented villi and 30 corresponding crypts. For the histochemical evaluation of gut mucins, other representative sections were stained with Alcian blue $\mathrm{pH} 2.5$ (AB 2.5) for the demonstration of acidic mucins and with periodic acid-Schiff base (PAS) for identification of neutral mucins. Goblet cells in the intestinal mucosa stained with AB 2.5 and PAS were counted in 10 well-oriented villi and 10 corresponding crypts. All measurements of the stained sections were performed using the light microscope (Zeiss type Axiostar Plus with Axio Vision LE Rel 4.5 software) with $10 \mathrm{x}$ or $5 \mathrm{x}$ objective. Threonine dehydrogenase activity was determined by the method described by Simpson (1998).

\section{Calculations and statistical analysis}

Metabolizable energy value of diets was calculated as a sum of energy of dietary components. Nitrogen retention was calculated as: $\mathrm{N}$ intake - (faecal $\mathrm{N}$ output + urinary $\mathrm{N}$ output). 
Results were expressed as the means of six pigs. Data were statistically evaluated using Statistica 8.0 PL (Stat Soft, 1997) with one-way ANOVA followed by the Tuckey post-hoc test or one-way Kruskal-Wallis ANOVA followed by the Mann-Whitney test.

\section{RESULTS}

\section{Growth performance and $N$ retention}

No significant effect of increasing Thr level on ADG and F/G was observed (Table 2), however numerically lower ADG (469 vs 477-489 g) and higher F/G (1.65 vs 1.58-1.63) were found in pigs fed Thr-unsupplemented diet, as compared with other groups. Results of $\mathrm{N}$ balance are shown in Table 3. Significant decrease in $\mathrm{N}$ retention, expressed in g per day, was found in pigs fed Thr-deficient diet as compared with diets containing 7.43 and $9.32 \mathrm{~g}$ Thr per $\mathrm{kg}(\mathrm{P}<0.05)$. However, significant difference in $\mathrm{N}$ retention, expressed as a percentage of daily $\mathrm{N}$ intake, was observed only between pigs fed diets containing 6.46 and $9.32 \mathrm{~g}$ Thr per $\mathrm{kg}$ $(\mathrm{P}<0.05)$.

Table 2. Growth performance in pigs fed on diets containing different levels of threonine

\begin{tabular}{|c|c|c|c|c|c|c|}
\hline \multirow{2}{*}{ Item } & \multicolumn{4}{|c|}{ Threonine, $\mathrm{g} / \mathrm{kg}$ diet } & \multirow[b]{2}{*}{ SEM } & \multirow[b]{2}{*}{$\mathrm{P}$} \\
\hline & 6.46 & 7.43 & 8.37 & 9.32 & & \\
\hline Initial $\mathrm{BW}^{1}, \mathrm{~kg}$ & 13.1 & 12.9 & 13.0 & 12.7 & & \\
\hline Final BW, kg & 21.6 & 21.5 & 21.8 & 21.6 & & \\
\hline $\mathrm{ADG}^{2}, \mathrm{~g}$ & 469 & 477 & 489 & 478 & 13.7 & 0.641 \\
\hline $\mathrm{F} / \mathrm{G}^{3}, \mathrm{~kg} / \mathrm{kg}$ & 1.65 & 1.63 & 1.58 & 1.62 & 0.05 & 0.641 \\
\hline
\end{tabular}

${ }^{1} \mathrm{BW}$ - body weight; ${ }^{2} \mathrm{ADG}$ - average daily gain; ${ }^{3} \mathrm{~F} / \mathrm{G}$ - feed:gain ratio

Table 3. Nitrogen balance in pigs fed on diets containing different levels of threonine

\begin{tabular}{|c|c|c|c|c|c|c|}
\hline \multirow{2}{*}{ Item } & \multicolumn{4}{|c|}{ Threonine, $\mathrm{g} / \mathrm{kg}$ diet } & \multirow{2}{*}{ SEM } & \multirow{2}{*}{$\mathrm{P}$} \\
\hline & 6.46 & 7.43 & 8.37 & 9.32 & & \\
\hline $\mathrm{N}$ intake, $\mathrm{g} / \mathrm{d}$ & 25.7 & 25.7 & 25.7 & 25.7 & & \\
\hline $\mathrm{N}$ excretion, $\mathrm{g} / \mathrm{d}$ & $12.0^{\mathrm{b}}$ & $10.7^{\mathrm{a}}$ & $10.7^{\mathrm{ab}}$ & $10.9^{\mathrm{a}}$ & 0.3 & 0.034 \\
\hline $\mathrm{N}$ retention, $\mathrm{g} / \mathrm{d}$ & $13.7^{\mathrm{a}}$ & $15.0^{\mathrm{b}}$ & $15.0^{\mathrm{ab}}$ & $14.8^{\mathrm{b}}$ & 0.9 & 0.048 \\
\hline$\underline{\mathrm{N} \text { retention, } \% \mathrm{~N} \text { intake }}$ & $53.2^{\mathrm{a}}$ & $58.4^{\mathrm{ab}}$ & $58.5^{\mathrm{ab}}$ & $57.6^{\mathrm{b}}$ & 4.2 & 0.012 \\
\hline
\end{tabular}

$\mathrm{a,b}$ - values in the same row with different superscripts differ at $\mathrm{P}<0.05$

\section{Morphology of the small intestine}

Experimental diets had no effect on weight of the segments of the small intestine (data not shown), while they modified their morphometry (Table 4). 
Table 4. Histological parameters of three parts of the small intestine in pigs fed on diets containing different levels of threonine.

\begin{tabular}{|c|c|c|c|c|c|c|}
\hline \multirow{2}{*}{ Item } & \multicolumn{4}{|c|}{ Threonine, $\mathrm{g} / \mathrm{kg}$ diet } & \multirow{2}{*}{ SEM } & \multirow{2}{*}{$\mathrm{P}$} \\
\hline & 6.46 & 7.43 & 8.37 & 9.32 & & \\
\hline \multicolumn{7}{|l|}{ Duodenum } \\
\hline villi length, $\mu \mathrm{m}$ & $339^{\mathrm{a}}$ & $366^{\mathrm{b}}$ & $368^{\mathrm{b}}$ & $357^{\mathrm{b}}$ & 5.0 & 0.001 \\
\hline crypt depth, $\mu \mathrm{m}$ & $249^{\mathrm{a}}$ & $249^{a}$ & $275^{\mathrm{b}}$ & $256^{\mathrm{a}}$ & 4.3 & 0.001 \\
\hline villi length to crypt depth ratio & $1.47^{\mathrm{a}}$ & $1.56^{\mathrm{b}}$ & $1.39^{\mathrm{a}}$ & $1.46^{\mathrm{a}}$ & 0.03 & 0.014 \\
\hline tunica mucosa thickness, $\mu \mathrm{m}$ & $749^{\mathrm{a}}$ & $779^{\mathrm{b}}$ & $788^{\mathrm{b}}$ & $775^{\mathrm{b}}$ & 6.5 & 0.001 \\
\hline myenteron thickness, $\mu \mathrm{m}$ & $282^{\mathrm{c}}$ & $237^{\mathrm{a}}$ & $270^{\mathrm{b}}$ & $262^{\mathrm{b}}$ & 4.2 & 0.001 \\
\hline villi surface area, $\mathrm{mm}^{2}$ & $0.21^{\mathrm{a}}$ & $0.23^{\mathrm{b}}$ & $0.23^{\mathrm{b}}$ & $0.22^{\mathrm{a}}$ & 0.01 & 0.003 \\
\hline \multicolumn{7}{|l|}{ Mid-jejunum } \\
\hline villi length, $\mu \mathrm{m}$ & $403^{\mathrm{b}}$ & $394^{\mathrm{ab}}$ & $384^{\mathrm{a}}$ & $381^{\mathrm{a}}$ & 5.5 & 0.034 \\
\hline crypt depth, $\mu \mathrm{m}$ & 270 & 247 & 254 & 245 & 8.0 & 0.097 \\
\hline villi length to crypt depth ratio & 1.68 & 1.67 & 1.65 & 1.65 & 0.06 & 0.162 \\
\hline tunica mucosa thickness, $\mu \mathrm{m}$ & $685^{\mathrm{a}}$ & $740^{\mathrm{c}}$ & $718^{\mathrm{b}}$ & $719^{\mathrm{b}}$ & 7.4 & 0.001 \\
\hline myenteron thickness, $\mu \mathrm{m}$ & $212^{\mathrm{a}}$ & $222^{\mathrm{b}}$ & $262^{\mathrm{c}}$ & $247^{\mathrm{c}}$ & 4.7 & 0.001 \\
\hline villi surface area, $\mathrm{mm}^{2}$ & $0.22^{b}$ & $0.22^{b}$ & $0.23^{\mathrm{ab}}$ & $0.20^{\mathrm{a}}$ & 0.01 & 0.01 \\
\hline \multicolumn{7}{|l|}{ Ileum } \\
\hline villi length, $\mu \mathrm{m}$ & 356 & 347 & 349 & 349 & 4.7 & 0.053 \\
\hline crypt depth, $\mu \mathrm{m}$ & $239^{\mathrm{a}}$ & $266^{c}$ & $248^{\mathrm{b}}$ & $236^{\mathrm{a}}$ & 13.1 & 0.001 \\
\hline villi length to crypt depth ratio & $1.59^{\mathrm{b}}$ & $1.38^{\mathrm{ab}}$ & $1.47^{\mathrm{a}}$ & $1.57^{\mathrm{c}}$ & 0.03 & 0.001 \\
\hline tunica mucosa thickness, $\mu \mathrm{m}$ & $626^{\mathrm{a}}$ & $670^{\mathrm{b}}$ & $661^{\mathrm{b}}$ & $659^{\mathrm{b}}$ & 6.5 & 0.001 \\
\hline myenteron thickness, $\mu \mathrm{m}$ & $342^{\mathrm{a}}$ & $353^{\mathrm{ab}}$ & $347^{\mathrm{b}}$ & $366^{\mathrm{c}}$ & 11.3 & 0.001 \\
\hline villi surface area, $\mathrm{mm}^{2}$ & 0.20 & 0.19 & 0.19 & 0.20 & 0.01 & 0.057 \\
\hline
\end{tabular}

a,b,c - values in the same row with different superscripts differ at $\mathrm{P} \leq 0.05$

Villi length differed only between pigs fed Thr-deficient diet and Thrsupplemented diets and was the lowest in the duodenum $(\mathrm{P}<0.001)$ and highest in the mid-jejunum $(\mathrm{P}<0.05)$. Level of supplementation did not affect villi length in either segment under study. Both, crypt depth and villi length to crypt depth ratio differed between the groups in the duodenum and ileum in an irregular way. In all segments, tunica mucosa thickness was significantly smaller $(\mathrm{P}<0.001)$ in pigs fed Thr-deficient diet compared with groups fed higher Thr levels. The myenteron thickness was also affected and in pigs fed Thr-deficient diet was significantly bigger $(\mathrm{P}<0.001)$ in the duodenum and smaller $(\mathrm{P}<0.001)$ in the mid-jejunum and ileum. In all groups, some changes were also observed in villi surface area, however, the differences were small and were not influenced by Thr level.

\section{Goblet cells number in the small intestine}

The number of GC containing acidic and neutral mucins in three segments of the small intestine are presented in Table 5. Dietary Thr level differently affected number of GC in particular segments. In the duodenum, comparatively 
lower $(\mathrm{P}<0.01)$ number of GC containing neutral mucins were observed in crypts after feeding two diets with lower Thr level and lower $(\mathrm{P}<0.01)$ number of GC containing acidic mucins in villi after feeding diet containing $7.43 \mathrm{~g}$ Thr per $\mathrm{kg}$. In the mid-jejunum, both the lowest and the highest Thr level decreased $(\mathrm{P}<0.001)$ number of neutral type GC in villi $(\mathrm{P}<0.01)$ and number of acidic type GC in crypts. In the ileum, the greatest number of GC both in villi and crypts was found in pigs fed the diet with the highest Thr level.

Table 5. Goblet cell number containing neutral or acid mucins per villous and per crypt in the small intestine in pigs fed on diets containing different levels of threonine

\begin{tabular}{|c|c|c|c|c|c|c|}
\hline \multirow{2}{*}{ Item } & \multicolumn{4}{|c|}{ Threonine, $\mathrm{g} / \mathrm{kg}$ diet } & \multirow{2}{*}{ SEM } & \multirow{2}{*}{$\mathrm{P}$} \\
\hline & 6.46 & 7.43 & 8.37 & 9.32 & & \\
\hline \multicolumn{7}{|l|}{ Duodenum } \\
\hline neutral in villi & 8.4 & 8.2 & 9.4 & 9.2 & 0.6 & 0.149 \\
\hline acidic in villi & $10.8^{\mathrm{b}}$ & $7.8^{\mathrm{a}}$ & $10.0^{\mathrm{b}}$ & $11.0^{\mathrm{b}}$ & 0.6 & 0.003 \\
\hline neutral in crypts & $5.8^{\mathrm{a}}$ & $6.6^{\mathrm{ab}}$ & $7.2^{\mathrm{b}}$ & $6.9^{\mathrm{b}}$ & 0.3 & 0.004 \\
\hline acidic in crypts & 8.5 & 8.5 & 7.9 & 8.1 & 0.4 & 0.608 \\
\hline \multicolumn{7}{|l|}{ Mid-jejunum } \\
\hline neutral in villi & $4.8^{\mathrm{a}}$ & $7.0^{\mathrm{b}}$ & $6.8^{\mathrm{b}}$ & $5.8^{\mathrm{ab}}$ & 0.4 & 0.001 \\
\hline acidic in villi & 6.2 & 7.4 & 7.2 & 6.4 & 0.4 & 0.321 \\
\hline neutral in crypts & 4.8 & 4.8 & 4.9 & 4.7 & 0.2 & 0.944 \\
\hline acidic in crypts & $5.5^{\mathrm{a}}$ & $7.2^{\mathrm{b}}$ & $6.8^{\mathrm{b}}$ & $5.2^{\mathrm{a}}$ & 0.3 & 0.001 \\
\hline \multicolumn{7}{|l|}{ Ileum } \\
\hline neutral in villi & $8.8^{\mathrm{a}}$ & $9.0^{\mathrm{a}}$ & $9.0^{\mathrm{a}}$ & $11.0^{\mathrm{b}}$ & 0.6 & 0.046 \\
\hline acidic in villi & $10.0^{\mathrm{a}}$ & $10.6^{\mathrm{a}}$ & $10.4^{\mathrm{a}}$ & $13.4^{\mathrm{b}}$ & 0.8 & 0.015 \\
\hline neutral in crypts & $9.8^{\mathrm{a}}$ & $11.2^{\mathrm{b}}$ & $11.3^{\mathrm{b}}$ & $12.7^{\mathrm{c}}$ & 0.4 & 0.001 \\
\hline acidic in crypts & $15.3^{\mathrm{a}}$ & $14.2^{\mathrm{a}}$ & $15.6^{\mathrm{ab}}$ & $16.8^{\mathrm{b}}$ & 0.7 & 0.042 \\
\hline
\end{tabular}

\section{Threonine dehydrogenase activity}

Dietary treatments did not affect the weight of liver and pancreas (data not shown) and TDG activity (Table 6). Activity of the enzyme was higher in pancreas $(0.33-0.41 \mu \mathrm{mol} / \mathrm{min} / \mathrm{g})$ compared with liver $(0.18-0.24 \mu \mathrm{mol} / \mathrm{min} / \mathrm{g})$.

Table 6. Threonine dehydrogenase activity $(\mu \mathrm{mol} / \mathrm{min} / \mathrm{g})$ in the liver and pancreas of pigs fed on diets containing different levels of threonine

\begin{tabular}{|c|c|c|c|c|c|c|}
\hline \multirow{2}{*}{ Item } & \multicolumn{4}{|c|}{ Threonine, $\mathrm{g} / \mathrm{kg}$ diet } & \multirow{2}{*}{ SEM } & \multirow{2}{*}{$P$} \\
\hline & 6.46 & 7.43 & 8.37 & 9.32 & & \\
\hline Liver & 0.22 & 0.24 & 0.24 & 0.18 & 0.05 & 0.736 \\
\hline Pancreas & 0.33 & 0.41 & 0.37 & 0.36 & 0.07 & 0.905 \\
\hline
\end{tabular}




\section{DISCUSSION}

In the present study it was shown that the lowest Thr level ( $6.46 \mathrm{~g}$ per kg diet) affected negatively both protein retention and intestinal structure. The applied low Thr level was higher than that used by Russel et al. (1986) for pigs weighing from 17 to $38 \mathrm{~kg}$ ( $6.0 \mathrm{~g}$ Thr per $\mathrm{kg}$ diet). The highest Thr level (9.32 g per kg) was much higher than that advised by NRC (1998) and GfE (2006) for piglets weighing from 10 to $20 \mathrm{~kg}$.

In our study, Thr increase in a diet to $7.43 \mathrm{~g}$ per $\mathrm{kg}$ had positive effect on $\mathrm{N}$ balance, but did not affect significantly growth parameters of the pigs. Only, some tendency to lower ADG and higher F/G ratio was observed in pigs fed the lowest Thr diet compared with the other diets (Table 2). These results are in agreement with the studies of Hamard et al. (2007) and Law et al. (2007) who observed that growth of early weaned piglets was not affected by Thr deficiency when 70 and $17 \%$ of Thr requirement was covered in the respective studies. The lack of effect of Thr deficiency observed in these studies was probably due to a short time of feeding deficient diets ( 14 and 8 days, respectively), not sufficient to get differences in growth. On the contrary, results of several studies on weaning piglets (Adeola et al., 1994; Wang et al., 2007; Wang et al., 2010), growing pigs (Le Floc'h et al., 1994), and finishing pigs (Plitzner et al., 2007) showed that growth performance parameters were negatively affected by low Thr supply.

Gatel and Fekete (1989) reported that maximal growth rate of pigs weighing from 10 to $25 \mathrm{~kg}$ pigs was obtained by feeding a diet containing $7.5 \mathrm{~g}$ Thr per $\mathrm{kg}$, which was close to the second $\mathrm{Thr}$ level $(7.43 \mathrm{~g}$ per $\mathrm{kg})$ used in the present study. However, Conway et al. (1990) showed that $7.8 \mathrm{~g}$ Thr per kg diet was optimal for maximal growth of pigs from 17 to $50 \mathrm{~kg}$. In Wang et al. (2007) study, maximal growth rate of piglets weighing from 5 to $10 \mathrm{~kg}$ was observed when feeding diet containing $8.4 \mathrm{~g}$ Thr per $\mathrm{kg}$, which was close to the third Thr level (8.37 g per kg) used in the present study on hevier piglets.

In our study, increasing Thr level from 6.46 to $7.43 \mathrm{~g}$ per $\mathrm{kg}$ significantly increased daily $\mathrm{N}$ retention ( $\mathrm{g}$ per day). Further increases in Thr level to 8.37 and $9.32 \mathrm{~g}$ per kg failed to increase $\mathrm{N}$ retention. Nutritional effects of the experimental diets were not limited by other factors as they were formulated to cover the piglet requirement for energy and AA (GfE, 2006).

The level of Thr applied in our study: 6.46, 7.43, 8.37 and $9.32 \mathrm{~g}$ per kg/ diet correspond to $0.48,0.55,0.62$ and 0.69 threonine to lysine ratio, respectively. Recommended threonine to lysine ratio for young pigs is 0.60 (GfE, 2006), which is close to the third Thr level used in the present study.

In this study, it was shown that dietary Thr level had no effect on length and weight of the small intestine, but provoked some changes in morphology. In 
particular, the Thr-deficient diet (containing about $87 \%$ of the AA as compared to the diet with the second Thr level) affected significantly villi length in the duodenum and decreased tunica mucosa thickness in all segments of the small intestine compared with other diets (Table 4). Other changes in intestinal morphology were not related to dietary Thr level. In our previous study on the older pigs (Święch et al., 2010) moderate Thr-deficiency had no effect on the weight of the small intestine and had a marginal effect on morphology in all segments of the intestine as it reduced crypt depth in the duodenum and mid-jejunum and reduced thickness of tunica mucosa in the duodenum and myenteron in the ileum. Using diets with greater Thr deficiency, Hamard et al. (2007) found that length and weight of the small intestine in early weaned piglets were not altered by Thr deficient diet ( $70 \%$ of Thr requirement), but villi length and villi/crypt ratio were reduced in the ileum. Law et al. (2007) showed that very low Thr supply (only $17 \%$ of Thr requirement) for eight days significantly decreased villi length and villi/crypt ratio in the mid-jejunum and ileum. The villi atrophy observed in the ileum was probably caused by lack of Thr. Schaart et al. (2005) showed that most of the dietary free $\mathrm{Thr}$ was incorporated into intestinal protein in the proximal part of the small intestine. Results of Wang et al. (2010) showed villi atrophy in the duodenum and ileum in piglets fed Thr-deficient (50\% of requirement) and Threxcess ( $150 \%$ of requirement) diets.

Mucin secretion is sensitive to dietary Thr supply (Bertolo et al., 1998; Wang et al., 2007). In the present study, it was shown that goblet cell morphology was affected by dietary Thr level. However, the effect of Thr on GC number containing neutral and acidic mucins in villi and crypts in three segments of the small intestine was differentiated and is difficult for interpretation. Generally, feeding the Thr-deficient diet (6.46 g Thr per $\mathrm{kg}$ ) reduced the number of GC in the small intestine compared with Thr supplemented diets (Table 5). However, reduction of in villi GC containing neutral mucins and crypt GC containing acidic mucins were also observed after feeding the highest Thr level, but only in the mid-jejunum. In contrast, this diet affected positively the number of all types GC in the ileum. Results of studies of Law et al. (2007) and Wang et al. (2010) showed reduction in numbers of acidic mucin-producing GC in the duodenum and ileum in early weaned piglets fed both Thr-deficient and Thr-excess diets. On the contrary, number of mucin-containing GC in villi and crypts in the small intestine was not affected by Thr level in early weaned piglets (Hamard et al., 2007). Similarly, in finishing pigs no effect of dietary Thr on GC number was observed (Plitzner et al., 2007). Both, our and literature results concerning modification in the morphology of the small intestine are equivocal and cannot support an assumption that high Thr supplementation benefits mucosal health. 
In the present study TDG activity in the liver and pancreas was not affected by dietary Thr level. These results are not in agreement with our previous study (Święch et al., 2010), in which TDG in the liver and pancreas was three and two times higher, respectively, in pigs fed on Thr-adequate than on Thr-deficient diet. Different results were also obtained by Le Floc'h et al. (1995; 1996), who found significantly lower TDG only in one tissue (pancreas or liver) in pig fed Thrdeficient diet compared with positive control diet.

\section{CONCLUSIONS}

It can be assumed that the level of threonine (Thr) amounting about $7.4 \mathrm{~g}$ Thr per $\mathrm{kg}$ covers the requirement of piglets from 10 to $25 \mathrm{~kg}$ for rapid growth and maximal $\mathrm{N}$ retention. Whether this level of Thr is optimal for intestinal health, it remains to be proved.

\section{REFERENCES}

Adeola O., Lawrence B.V., Cline T.R., 1994. Availibility of amino acids for 10- to 20-kilogram pigs: lysine and threonine in soybean meal. J. Anim. Sci. 72, 2061-2067

AOAC, 1990. Association of Analitycal Chemists, Official Methods of Analysis. 15 ${ }^{\text {th }}$ Edition. Washington, DC

Bertolo R.F.P., Chen C.Z.L., Law G., Pencharz P.B., Ball R.O., 1998. Threonine requirement of neonantal piglets receiving total parenteral nutrition is considerably lower than of piglets receiving an identical diet intragastrically. J. Nutr. 128, 1752-1759

Buraczewska L., Buraczewski S., 1984. A note on determination of methionine and tryptophan. In: Proceeding of $6^{\text {th }}$ International Symposium on Amino Acids. Serock (Poland). Polish Scientific Publishers, Warsaw, pp. 47-50

Buraczewska L., Święch E., Le Bellego L., 2006. Nitrogen retention and growth performance of 25 to $50 \mathrm{~kg}$ pigs fed diets of two protein levels and different ratio of digestible threonine to lysine. J. Anim. Feed Sci. 15, 25-36

Conway D., Sauer W.C., den Hartog L.A., Huisman J., 1990. Studies on the threonine requirements of growing pigs based on the total, ileal and faecal digestible content. Livest. Prod. Sci. 25, 105-120

Deplancke B., Gaskins H.R., 2001. Microbial modulation of innate defense: goblet cells and the intestinal mucus layer. Amer. J. Clin. Nutr. 73, 1131S-1141S

Fuller M.F., McWilliam R., Wang T.C., Giles L.R., 1989. The optimum dietary amino acid pattern for growing pigs. 2. Requirements for maintenance and for tissue protein accretion. Brit. J. Nutr. 62, 255-267

Gatel F., Fekete J., 1989. Lysine and threonine balance and requirements for weaned piglets 10-25 $\mathrm{kg}$ liveweight fed cereal-based diets. Livest. Prod. Sci. 23, 195-206

GfE Gasellschaft für Ernährungsphysiologie), 2006. Recommendations for the Supply of Energy and Nutrients to Pigs. Committee for Requirement Standards of the Society of Nutrition Physiology. DLG-Verlag Frankfurt am Main 
Hamard A., Séve B., Le Floc'h N., 2007. Intestinal development and growth performance of earlyweaned piglets fed a low-threonine diet. Animal 1, 1134-1142

Law G.K., Bertolo R.F., Adjiri-Awere A., Pencharz P.B., Ball R.O., 2007. Adequate oral threonine is critical for mucin production and gut function in neonantal piglets. Amer. J. Physiol.Gastrointest. L. 292, G1293-G1301

Le Floc'h N., Obled C., Séve B., 1995. In vivo threonine oxidation rate is dependent on threonine dietary supply in growing pigs fed low to adequate levels. J. Nutr. 125, 2550-2562

Le Floc'h N., Obled C., Séve B., 1996. In vivo threonine oxidation in growing pigs fed on diets with graded levels of threonine. Brit. J. Nutr. 75, 825-837

Le Floc'h N., Séve B., 2005. Catabolism through the threonine dehydrogenase pathway does not account for the high first-pass extraction rate dietary threonine by the portal drained viscera in pigs. Brit. J. Nutr. 93, 447-456

Le Floc'h N., Séve B., Henry Y., 1994. The addition of glutamic acid to protein to a threoninedeficient diet differentially affects growth performance and threonine dehydrogenase activity in fattening pigs. J. Nutr. 124, 1987-1995

Le Floc'h N., Tibault J.-N., Séve B., 1997. Tissue localization of threonine oxidation in pigs. Brit. J. Nutr. 77, 593-603

NRC, 1998. Nutrient Requirements of Swine. $10^{\text {th }}$ Edition. National Academy Press, Washington, $\mathrm{DC}$

Plitzner C., Ettle T., Handl S., Schmidt P., Windisch W., 2007. Effects of different dietary threonine levels on growth and slaughter performance in finishing pigs. Czech. J. Anim. Sci. 52, $447-$ 455

Russell L.E., Easter R.A., Gomez-Rojas V., Cromwell G.L., Stahly T.S., 1986. A note on the supplementation of low protein, maize-soya-bean meal diets with lysine, threonine, and methionine for growing pigs. Anim. Prod. 42, 291-295

Saldana C.I., Knabe D.A., Owen K.Q., Burgoon K.G., Gregg E.J., 1994. Digestible threonine requirements of starter and finisher pigs. J. Anim. Sci. 72, 144-150

Schaart M.W., Schierbeek H., van der Schoore S.R.D., Stoll B., Burrin D.G., Reeds P.J., van Goudouever J.B., 2005. Threonine utilization is high in the intestine in piglets. J. Nutr. 135, 765-770

Simpson G.J., 1998. Development of methods to improve the estimation of threonine catabolism in the growing pigs, MSc Thesis, University of Guelph. Guelph (Canada)

StatSoft Inc., 1997. Statistica 8.0 PL for Windows, Tulsa (USA)

Stoll B., Henry J., Reeds P.J., Yu H., Jahor F., Burrin D.G., 1998. Catabolism dominates the firstpass intestinal metabolism of dietary essential amino acids in milk protein-fed piglets. J. Nutr. 128, 606-614

Święch E., Buraczewska L., Tuśnio A., Taciak M., 2010. The effects of supplementing a low-protein threonine-deficient diet with different sources of non-essential amino acids on nitrogen retention and gut structure in young pigs. Arch. Anim. Nutr. 64, 22-35

Wang X., Qiao S., Yin Y., Yue L., Wang Z., Wu G., 2007. A deficiency or excess of dietary threonine reduces protein synthesis in jejunum and skeletal muscle of young pigs. J. Nutr. 137, 14421446

Wang W., Zeng X., Mao X., Wu G., Qiao S., 2010. Optimal dietary true ileal digestible threonine for supporting the mucosal barrier in small intestine of weanling pigs. J. Nutr. 140, 981-986 